\title{
BAD Gene
}

National Cancer Institute

\section{Source}

National Cancer Institute. BAD Gene. NCI Thesaurus. Code C20414.

The gene plays a role in the positive regulation of cellular apoptosis. 